Original scientific paper - Izvorni znanstveni rad

UDK: 637.065

\title{
Presence of Fusarium mycotoxins in feedstuffs and cow milk sampled from Croatian farms during 2015
}

doi: 10.15567/mljekarstvo.2017.0202

\author{
Jelka Pleadin ${ }^{1}$, Ana Vulićl , Manuela Zadravec ${ }^{2 *}$, Tina Lešić ${ }^{1}$, \\ Miroslav Benić ${ }^{3}$,Vesna Jaki Tkalec ${ }^{4}$, Nada Vahčić ${ }^{5}$ \\ ${ }^{1}$ Croatian Veterinary Institute, Laboratory for Analytical Chemistry, \\ Savska Cesta 143, 10000 Zagreb, Croatia \\ ${ }^{2}$ Croatian Veterinary Institute, Laboratory for Microbiology of Feed, \\ Savska Cesta 143, 10000 Zagreb, Croatia \\ ${ }^{3}$ Croatian Veterinary Institute, Laboratory for Mastitis and Raw Milk Quality, \\ Savska Cesta 143, 10000 Zagreb, Croatia \\ ${ }^{4}$ Croatian Veterinary Institute, Veterinary Centre Križevci, \\ Ivana Z. Dijankovečkog 10, 48260 Križevci, Croatia \\ ${ }^{5}$ University of Zagreb, Faculty of Food Technology and Biotechnology, \\ Pierottijeva 6, 10000 Zagreb, Croatia
}

Received - Prispjelo: 25.07.2016. Accepted - Prihvaćeno: 06.04.2017.

\begin{abstract}
Mycotoxins may contaminate food of animal origin due to the carry-over effect and represent a potential risk to human health. The problem of Fusarium mycotoxin contamination becomes an issue especially during rainy years characterised by substantial temperature changes. The aim of this study was to investigate into the level of Fusarium mycotoxins zearalenone (ZEN), deoxynivalenol (DON) and fumonisins (FUM) in maize silage $(n=21)$, concentrated dairy cattle feeds $(n=56)$ and cow milk samples $(n=105)$, taken during 2015 from households located in four Croatian regions. The presence of mycotoxins was determined using validated ELISA methods. A high level of feedstuffs' contamination was evidenced, especially with ZEN, with values higher than recommended observed in $9.5 \%$ of maize silage samples. Fourteen point three percent (14.3\%) of milk samples were DON positive, with the toxin concentrations ranging from 5.4 to $67.3 \mu \mathrm{g} / \mathrm{L}$. ZEN was determined in $94.3 \%$ of milk samples, ranging from 0.3 to $88.6 \mu \mathrm{g} / \mathrm{L}$. FUM were not detected in any of the analysed milk samples. Given the tolerable daily intakes (TDIs) defined for these mycotoxins, human health risks arising from the consumption of cow milk can generally be considered low, even in times characterised by weather conditions that facilitate the production of Fusarium mycotoxins in cereals subsequently used as dairy cattle feed. The exception represents particular milk samples in which high ZEN concentrations were found.
\end{abstract}

Key words: Fusarium mycotoxins, cow milk, dairy cattle, feedstuffs, Croatian farms

\section{Introduction}

As natural and unavoidable contaminants of important agricultural commodities, mycotoxins have continued to severely impact animal and human health (Coffey et al., 2009). Mycotoxins of the
Fusarium species have traditionally been associated with cereal contamination (Glenn, 2007) that may occur before harvest (in the field) and/or after it (in warehouses and silos). The level of contamination also depends on the storage methods and conditions, and varies across geographical areas and climatic

*Corresponding author/Dopisni autor: E-mail: zadravec@veinst.hr 
regions, influenced by the formation of moulds, moisture level, temperature, aeration, the presence of insects and mechanical damage to the cereals stored (Placinta et al., 1999; Pleadin et al., 2015). Studies have shown that the problem of Fusarium mycotoxin contamination emerges in particular during rainy years characterised by substantial temperature changes (Pleadin et al., 2012a; Pleadin et al., 2012b).

Residues of mycotoxins may be present in eggs, milk, meat and offal due to the carry-over effect and represent a potential risk to humans (Yiannikouris and Jouany, 2002; Cavret and Lecoeur, 2006; Fink-Gremmels, 2008). In ruminants, the rumen flora can convert a number of mycotoxins into metabolites of lower or no health risk. The rumen of healthy animals is thus an important barrier, which can be impaired due to various ruminant diseases. In comparison to monogastric animals such as pigs, ruminants are generally more resistant to adverse effects of mycotoxins, since the microorganisms in the rumen have the ability to degrade these mycotoxins into less toxic compounds (Keese et al., 2008). In cows, the presence of zearalenone or the Fusarium species producing this mycotoxin has been associated with infertility, reduced milk production and hyperestrogenism (Warth et al., 2013). Dairy cows are considerably more tolerant to deoxynivalenol, as exemplified by the lack of any adverse impact on feed intake and milk production (D'Mello et al., 1999).

The excretion of mycotoxins through milk is generally low and is affected by molecular weight and lipophilicity of a mycotoxin. The transport rate is also influenced by the $\mathrm{pH}$ gradient between blood plasma and milk, which changes according to cow's health (Coffey et al., 2009; Kalač, 2011). Mycotoxin analysis of biological samples enables not only the evaluation of exposure to these contaminants, but also the assessment of consumer risk arising on the grounds of contaminated foodstuffs of animal origin (Dänicke and Winkler, 2015). At the same time, it is known that cow milk is an important component of diet of humans of all ages, since it provides important nutrients. Children are especially frequent consumers of milk as one of the principal foodstuffs taken during the first years of life.

Given that data on natural occurrence of Fusarium mycotoxins in cow milk are scarce, the aim of this study was to determine the levels of the most representative Fusarium mycotoxins deoxinivalenol (DON), zearalenone (ZEN) and fumonisins (FUM) in cow milk taken from farms seated in four Croatian regions. During the same period, maize silage and concentrated dairy cattle feedstuffs were sampled from different farms and analysed for the presence of the abovementioned mycotoxins. Furthermore, the aim of this study was to compare the mycotoxin levels established in milk with the Tolerable Daily Intake (TDI) values defined for these mycotoxins, as well as to evaluate human health risks arising from the consumption of cow milk potentially contaminated with Fusarium mycotoxins.

\section{Materials and methods}

\section{Sampling and sample preparation}

Samples of dairy cattle feedstuffs, of which 21 samples of maize silage and 50 samples of concentrated cattle feeds were retrieved throughout 2015 from dairy farms situated in the northern (Varaždin, Međimurje, Koprivnica-Križevci and KrapinaZagorje County), central (Zagreb, Sisak-Moslavina and Bjelovar-Bilogora County), eastern (Slavonia, Baranja and Srijem County) and western (Istria and Gorski Kotar County) part of Croatia. Maize silage and cereals subsequently used for feed production were of the genus 2014 (used on farms during 2015). Sampling and preparation of the samples were performed in full line with the ISO 6497:2002 and ISO 6498:1998 standards, respectively. All samples of feedstuff were thoroughly ground in an analytical mill (Cylotec 1093, Tecator, Sweden) to achieve a particle size of $1.0 \mathrm{~mm}$ and were stored at $4{ }^{\circ} \mathrm{C}$ prior to analysis.

During 2015, a total of 105 cow milk samples were sampled from households also seated in the northern, central, eastern and western part of Croatia. Sampling of milk was performed in full line with the ISO 707:2008. All milk samples were fresh, not pre-treated, and were divided into groups based on the sampling region.

\section{Extraction of mycotoxins}

Feedstuffs: After grinding, five grams of each feedstuff sample were extracted using $25 \mathrm{~mL}$ of distilled water so as to be analysed for DON presence, 
or using $25 \mathrm{~mL}$ of methanol/water (70/30) solution so as to be analysed for ZEN and FUM presence. The extraction was performed by vigorous 3-minute shaking on a shaker, following which the extracts were filtered through a filter paper (Whatman, Black Ribbon, GE Healthcare, Buckinghamshire, United Kingdom). The supernatants obtained with all three analytes were appropriately diluted according to the ELISA kit manufacturer's instructions, and used for the determination of mycotoxin concentrations via the ELISA immunoassay.

Milk: Samples were centrifuged $(3,000 \mathrm{~g}$, $15 \mathrm{~min}$ ) at $4{ }^{\circ} \mathrm{C}$. The upper cream layers were removed. $20 \mu \mathrm{L}$ of glucoronidase/arylsulphatase Helix pomatia (Art No. 4114, Merck) were added to $1 \mathrm{~mL}$ of a sample, and incubated for $3 \mathrm{~h}$ at $37^{\circ} \mathrm{C}$. To $0.9 \mathrm{~mL}$ of hydrolyzed and defatted milk, $0.1 \mathrm{~mL}$ of methanol (to the effect of ZEN and FUM presence detection) or water (to the effect of DON presence detection) was added. The resulting solution $(50 \mu \mathrm{L})$ was used for analyses by the ELISA methods.

\section{Determination of mycotoxins using the ELISA}

The determination of mycotoxins concentration was performed using competitive RIDASCREEN ${ }^{\circledR}$ ELISA kits: DON (Art. No. R5906), Zearalenon (Art. No. R1401) and Fumonisin (determination of fumonisin B1, B2 and B3) (Art. No. R3401). Analytical steps were performed completely according to the test procedures declared by the kits' manufacturer (R-Biopharm, Darmstadt, Germany). The ELISA kits contained a micro-titre plate with 96 wells coated with antibodies, standard solutions containing different concentrations of mycotoxins, an enzyme conjugate, an anti-antibody, a substrate, a chromogen solution (urea peroxide/tetramethylbenzidine), a stop solution, and washing and dilution buffers. Standards employed with the validation of analytical methods were provided by Sigma-Aldrich Chemie $\mathrm{GmbH}$ (Steinheim, Germany). All other chemicals used for analyses were of an analytical grade.

ELISA tests were performed using a ChemWell auto-analyzer (Awareness Technology Inc. 2910, USA), where the absorbance thereby being measured at $450 \mathrm{~nm}$. In order to determine mycotoxin concentrations in milk samples, a standard curve illustrative of skim milk was plotted for each mycotoxin analysed. When establishing final mycotoxin concentrations in a given sample, the dilution factor and the mean recovery rate determined for each mycotoxin were taken into account.

\section{Validation of the ELISA method}

The limit of detection (LOD) and limit of quantification (LOQ) were calculated from the average of ten toxin-negative industrially produced milk samples (first analysed for the presence of Fusarium mycotoxins and then used for validation as a blank material) plus three-fold standard deviation (LOD $=$ mean $\pm 3 \mathrm{SD}$ ) and six-fold standard deviation (LOQ $=$ mean $\pm 6 \mathrm{SD}$ ), respectively. For each mycotoxin, the recovery rate was determined at two different levels (10 and $50 \mu \mathrm{g} / \mathrm{L}$ for DON and ZEA; 50 and $100 \mu \mathrm{g} / \mathrm{L}$ for FUM) by virtue of fortifying toxin-negative milk samples with standard working solution of the analysed mycotoxins $(200 \mu \mathrm{g} / \mathrm{L})$, followed by the analysis of three replicates at each "spiking" level.

\section{Estimation of mycotoxins intake}

The estimation of mycotoxins intake through the milk consumption pathways was made based on the data on average milk consumption published by the FAOSTAT (2014), link to published TDI values (EC 856/2005) and mean mycotoxins concentration determined in this study. According to FAOSTAT the average milk consumption in Croatia is $322 \mathrm{~g} / \mathrm{capita} /$ day and for the sake of calculations, the average body weight was estimated at $70 \mathrm{~kg}$ (EFSA, 2012). From these data amount of mycotoxin in a daily portion of milk was calculated and related to the given TDI values.

\section{Statistical analysis}

Statistical analysis was performed using the SPSS Statistics Software 22.0 (SPSS Statistics, NY, IBM, 2013). In order to determine the statistical significance of the differences between samples coming from different Croatian regions, the One-way ANOVA and the Tamhane's T2 post-hoc test were used. Statistical significance of data was estimated at the level of $\mathrm{p}<0.05$. 


\section{Results and discussion}

Some investigations have been conducted to assess the carry-over of Fusarium mycotoxins into edible tissues, eggs and milk (Flores-Flores et al., 2015). Published data show a limited deposition of these mycotoxins in meat and other edible tissues, and a low transmission rate into milk and eggs. It is known that mycotoxins are never completely removed from the feed-food chain, or from milk via pasteurisation, since the majority of them are heat-stable.

Earlier studies have concluded that, given that measurable Fusarium mycotoxin levels imply vast consumption, milk does not normally pose as a human health hazard arising from contaminated feeds lactating dairy cows are fed on (Prelusky et al., 1990; Dänicke and Winkler, 2015). However, some authors have emphasised the necessity for further investigations into the levels of Fusarium mycotoxins in milk (Coffey et al., 2009; Flores-Flores et al., 2015), especially in heavy rainfall periods characterised by significant temperature changes that favour the formation of these mycotoxins in cereals, consequently causing the contamination of dairy cow feeds.

In this study, the presence of mycotoxins in feedstuffs and milk was determined using the ELISA methods. The results of validation of the methods used for cow milk analyses are shown in Table 1 . The validation data pertaining to the methods used for the determination of these mycotoxins in feedstuffs (cereals) were published earlier (Pleadin et al., 2013).

LOD and LOQ values were the lowest for ZEA and the highest for FUM. Validation of the employed methodology resulted in the mean recovery rates of $80.4 \%$ for DON, $91.0 \%$ for ZEA and $79.0 \%$ for FUM, and in the coefficients of variation (CV) ranging from 5.8 to $11.4 \%$. Based on the obtained validation results and the validation criterion given under the Commission Decision 2002/657/EC (EC, 2002), the applied quantitative ELISA methods can be considered suitable for the determination of the investigated mycotoxins in milk. However, since the method employed in the determination of FUM shows high LOD and LOQ values, it can't be considered sensitive enough to be used for the determination of lower FUM levels in milk samples.

It is known that mycotoxin levels in maize silage and concentrated feeds are correlated with mycotoxin concentrations in milk (Signorini et al., 2012). In this study, dairy cows were fed on feedstuffs produced from cereals of the genus 2014, i.e. the cereals harvested in the year known for its heavy rainfall periods. Concentrations of Fusarium mycotoxins in feedstuffs sampled from Croatian dairy cow farms during 2015 are shown in Table 2. The obtained results are also displayed according to the sampling region (Table 3), although milk producers do not produce feedstuffs themselves but rather resort to centralised feed production taking place in feed mill plants from which the feed gets to be distributed across Croatia.

In total, DON was detected in $77 \%$, ZEN in $66 \%$, and FUM in $80 \%$ of maize silage and concentrated feed samples. DON and ZEA concentrations higher than recommended for dairy cattle feedstuffs under the Commission Recommendations 2006/576/EC (EC, 2006) were determined in $4.2 \%$ and $9.2 \%$ of samples, respectively. Although FUM concentrations were not higher than recommended in any of the samples, a significant level of contami-

Table 1. Results of validation of the ELISA method employed in the determination of mycotoxins in milk

\begin{tabular}{|c|c|c|c|c|c|}
\hline Mycotoxin & $\begin{array}{l}\text { LOD } \\
(\mu \mathrm{g} / \mathrm{L})\end{array}$ & $\begin{array}{c}\mathrm{LOQ} \\
(\mu \mathrm{g} / \mathrm{L})\end{array}$ & $\begin{array}{c}\text { Spiked level }{ }^{\mathrm{a}} \\
(\mu \mathrm{g} / \mathrm{kg})\end{array}$ & $\begin{array}{c}\text { Recovery } \\
(\%)\end{array}$ & $\begin{array}{l}\mathrm{CV} \\
(\%)\end{array}$ \\
\hline \multirow{2}{*}{ DON } & \multirow{2}{*}{4.0} & \multirow{2}{*}{5.4} & 10 & 78.5 & 5.8 \\
\hline & & & 50 & 82.3 & 6.1 \\
\hline \multirow{2}{*}{ ZEA } & \multirow{2}{*}{0.8} & \multirow{2}{*}{1.2} & 10 & 87.6 & 4.3 \\
\hline & & & 50 & 94.3 & 10.1 \\
\hline \multirow{2}{*}{ FUM } & \multirow{2}{*}{20.1} & \multirow{2}{*}{25.3} & 50 & 77.3 & 11.4 \\
\hline & & & 100 & 80.6 & 9.3 \\
\hline
\end{tabular}

DON - deoxynivalenol; ZEN - zearalenone; FUM - fumonisins; LOD - limit of detection; LOQ - limit of quantification; andustrial dairy milk was first analysed for mycotoxins under study and then utilised as a blank (mycotoxin-negative) material used for spiking during the recovery determination 
nation was observed, particularly in some maize silage samples (the maximal value of $6,300 \mu \mathrm{g} / \mathrm{kg}$ ). Generally, a high level of feedstuffs' contamination was observed, especially with ZEN, whose concentrations were higher than recommended in $9.5 \%$ of maize silage and $8.9 \%$ of concentrated feed samples. Mostly higher level of feedstuffs contamination was observed in Central and Eastern in comparison to Western and Northern part of Croatia, although not significantly different $(\mathrm{p}>0.05)$.
Given that high mycotoxin concentrations are usually associated with climatic conditions, in particular humidity and temperature as the factors most critical for mould formation and, thus, also mycotoxin production (Pleadin et al., 2013), high contamination of feedstuffs observed in this study could be explained by weather conditions evidenced during the period of cereal growth and harvesting. Official weather reports for 2014 show that in the period of cereal growth and harvesting (May-September), the

Table 2. Fusarium mycotoxins in maize silage and concentrated dairy cattle feed sampled from Croatian farms during 2015

\begin{tabular}{ccccccc}
\hline Mycotoxin & Material & $\begin{array}{c}\text { GV } \\
(\mu \mathrm{g} / \mathrm{kg})\end{array}$ & $\begin{array}{c}\text { \% over } \\
\mathrm{GV}^{\mathrm{a}}\end{array}$ & $\begin{array}{c}\text { \% of positives } \\
\text { b }\end{array}$ & $\begin{array}{c}\text { Mean } \pm \mathrm{SD} \\
(\mu \mathrm{g} / \mathrm{kg})\end{array}$ & $\begin{array}{c}\text { Range of positives } \\
(\mu \mathrm{g} / \mathrm{kg})\end{array}$ \\
\hline \multirow{2}{*}{ DON } & Silage & 10,000 & 4.8 & 81 & $3,879 \pm 4,893$ & $38.3-13,407$ \\
\cline { 2 - 7 } & Feed & 5,000 & 3.6 & 72 & $2,147 \pm 2,245$ & $24.1-10,120$ \\
\hline \multirow{2}{*}{ ZEN } & Silage & 3,000 & 9.5 & 74 & $2,084 \pm 2,723$ & $9.2-11,424$ \\
\cline { 2 - 7 } & Feed & 500 & 8.9 & 58 & $526 \pm 562$ & $5.7-2,298$ \\
\hline \multirow{2}{*}{ FUM } & Silage & 60,000 & 0 & 88 & $849 \pm 1,125$ & $49.3-6,300$ \\
\cline { 2 - 6 } & Feed & 50,000 & 0 & 71 & $855 \pm 865$ & $33.1-1,854$ \\
\hline
\end{tabular}

DON - deoxynivalenol; ZEN - zearalenone; FUM - fumonisins; GV - guidance value for feedstuffs given under the European Commission Recommendations 2006/576/EC;

a Samples in which mycotoxin concentrations were higher than the guidance value stated under the European Commission Recommendations 2006/576/EC;

bSamples in which mycotoxin concentrations were higher than the LOQ value;

Table 3. Fusarium mycotoxins in feedstuffs sampled in different Croatian regions during 2015

\begin{tabular}{|c|c|c|c|c|c|}
\hline Mycotoxin & Region & $\begin{array}{c}\text { No of } \\
\text { samples }\end{array}$ & $\%$ of positives ${ }^{a}$ & $\begin{array}{c}\text { Mean } \pm \text { SD } \\
(\mu \mathrm{g} / \mathrm{kg})\end{array}$ & $\begin{array}{c}\text { Range of positives } \\
(\mu \mathrm{g} / \mathrm{kg})\end{array}$ \\
\hline \multirow{5}{*}{ DON } & Central & 18 & 82 & $3,112 \pm 3,561$ & $24.1-9,256$ \\
\hline & Eastern & 25 & 84 & $4,293 \pm 4,591$ & $27.3-13,407$ \\
\hline & Western & 10 & 68 & $2,022 \pm 2,897$ & $46.2-9,302$ \\
\hline & Northern & 24 & 72 & $2,625 \pm 3,225$ & $26.3-11,402$ \\
\hline & In total & 77 & 77 & $3,013 \pm 3,569$ & $24.1-13,407$ \\
\hline \multirow{5}{*}{ ZEN } & Central & 18 & 75 & $1,516 \pm 2,011$ & $8.2-9,431$ \\
\hline & Eastern & 25 & 71 & $1,214 \pm 1,731$ & $10.1-11,424$ \\
\hline & Western & 10 & 56 & $1,112 \pm 1,093$ & $5.7-425$ \\
\hline & Northern & 24 & 62 & $1,377 \pm 1,735$ & $7.1-4,546$ \\
\hline & In total & 77 & 66 & $1,305 \pm 1,643$ & $5.7-11,424$ \\
\hline \multirow{5}{*}{ FUM } & Central & 18 & 85 & $925 \pm 1,231$ & $33.1-5,612$ \\
\hline & Eastern & 25 & 82 & $1,138 \pm 1,278$ & $52.4-6,300$ \\
\hline & Western & 10 & 72 & $631 \pm 614$ & $33.8-2,147$ \\
\hline & Northern & 24 & 79 & $715 \pm 856$ & $40.7-4,793$ \\
\hline & In total & 77 & 80 & $852 \pm 995$ & $33.1-6,300$ \\
\hline
\end{tabular}

DON - deoxynivalenol; ZEN - zearalenone; FUM - fumonisins;

aSamples in which mycotoxin concentrations were higher than the LOQ value 
investigated parts of Croatia were warm (75-91\%) to very warm (91-98\%) (MHS, 2014). As for the humidity, the year 2014 was highly (91-98\%) to extremely humid (>98\%). The obtained results, in terms of higher mean concentrations of Fusarium mycotoxins in maize silage and final feed products sampled in 2015 (genus 2014), could also be linked to the weather conditions witnessed in 2014 during the cereal growth and harvesting period. In that period high to very high temperatures and extreme humidity was observed, which could facilitate a significant mould growth and consequently also the production of these mycotoxins.

Table 4 shows concentrations of Fusarium mycotoxins in milk samples determined in different sampling regions an also expressed as the total value. FUM concentrations are not shown, since this mycotoxin was not detected in any of the milk samples analysed, meaning that FUM concentrations were actually lower than the ELISA method's LOQ (25.3 $\mu \mathrm{g} / \mathrm{L})$.

$14.3 \%$ of samples were determined to be DON positive, with the toxin concentrations ranging from 5.4 to $67.3 \mu \mathrm{g} / \mathrm{L}$ and the maximal concentration being determined in the Northern region. The maximal mean concentration was determined in the Central region $(28.8 \pm 30.6 \mu \mathrm{g} / \mathrm{L})$, while the maximal mean concentration determined in the Northern region was substantially lower $(9.1 \pm 6.3 \mu \mathrm{g} / \mathrm{L})$.
There was no statistically significant difference ( $p>0.05$ ) between the investigated regions. Studies have shown that in the rumen DON gets to be swiftly bio-transformed into deepoxy-deoxynivalenol (DOM-1), while its non-metabolized portion gets to be excreted into milk in an extremely low quantity (1-3 $\mu \mathrm{g} / \mathrm{L})$ (Côté et al., 1986; Keese et al., 2008). Galtier (1998) determined that DON transfer into cow milk is small (0.22 \%). After a single intravenous dose of 4,000 $\mu \mathrm{g} \mathrm{DON} / \mathrm{kg}$ body weight administered to ewes, Prelusky et al. (1987) determined $61 \mu \mathrm{g} / \mathrm{L}$ of DON and 1,220 $\mu \mathrm{g} / \mathrm{L}$ of DOM-1 in their milk. After the application of DON doses of 16,500 to $18,860 \mu \mathrm{g}$ DON $/ \mathrm{kg}$ b.w., the maximal DON concentration in milk was $17 \mu \mathrm{g} / \mathrm{L}$, while that of DOM-1 equalled to $205 \mu \mathrm{g} / \mathrm{L}$. Charmley et al. (1993) concluded that diets containing DON in concentrations of up to $6 \mathrm{mg} / \mathrm{kg}$ did not reduce cow feed intake and that DON and deepoxydeoxynivalenol were not transferred into milk. Higher DON concentrations observed in this study in some milk samples can be linked to an extremely high contamination evidenced in some of the maize silage and feed samples. Observed results can also be associated with possible liver dysfunction that impaired cow metabolism and resulted in the lesser conversion of DON into its metabolite DOM-1. In that case, the ELISA method used within the frame of this study is not specific enough to be able to determine it, as proclaimed also by the kit manufacturer.

Table 4. Fusarium mycotoxins in cow milk sampled in different Croatian regions during 2015

\begin{tabular}{ccccccc}
\hline \multirow{2}{*}{ Mycotoxin } & Region & $\begin{array}{c}\text { No of } \\
\text { positives }\end{array}$ & $\begin{array}{c}\% \text { of } \\
\text { positives }^{\mathrm{a}}\end{array}$ & $\begin{array}{c}\text { Mean } \pm \text { SD } \\
(\mu \mathrm{g} / \mathrm{L})\end{array}$ & $\begin{array}{c}\text { Median } \\
(\mu \mathrm{g} / \mathrm{L})\end{array}$ & $\begin{array}{c}\text { Range of } \\
\text { positives } \\
(\mu \mathrm{g} / \mathrm{L})\end{array}$ \\
\hline \multirow{5}{*}{ DON } & Central $(\mathrm{n}=29)$ & 5 & 17.2 & $28.8 \pm 30.6$ & 8.1 & $5.6-67.3$ \\
\cline { 2 - 7 } & Eastern $(\mathrm{n}=34)$ & 4 & 11.8 & $27.2 \pm 24.8$ & 25.6 & $5.7-52.0$ \\
\cline { 2 - 7 } & Western $(\mathrm{n}=14)$ & 3 & 21.4 & $19.4 \pm 10.9$ & 22.7 & $7.2-28.3$ \\
\cline { 2 - 7 } & Northern $(\mathrm{n}=28)$ & 3 & 10.7 & $9.1 \pm 6.3$ & 5.5 & $5.4-16.4$ \\
\cline { 2 - 7 } & In total $(\mathrm{n}=105)$ & 15 & 14.3 & $21.1 \pm 18.2$ & 8.1 & $5.4-67.3$ \\
\hline \multirow{3}{*}{ ZEN } & Central $(\mathrm{n}=29)$ & 27 & 93.1 & $8.3^{\mathrm{b}} \pm 22.3$ & 1.3 & $0.3-88.6$ \\
\cline { 2 - 7 } & Eastern $(\mathrm{n}=34)$ & 33 & 97.1 & $3.8^{\mathrm{b}} \pm 11.1$ & 1.6 & $0.5-60.3$ \\
\cline { 2 - 7 } & Western $(\mathrm{n}=14)$ & 13 & 92.9 & $2.0^{\mathrm{b}} \pm 2.5$ & 1.5 & $1.2-14.0$ \\
\cline { 2 - 7 } & Northern $(\mathrm{n}=28)$ & 26 & 92.9 & $7.8^{\mathrm{a}} \pm 12.0$ & 3.6 & $1.3-48.0$ \\
\cline { 2 - 7 } & In total $(\mathrm{n}=105)$ & 99 & 94.3 & $5.5 \pm 30.5$ & 1.6 & $0.3-88.6$ \\
\hline
\end{tabular}

$\mathrm{n}$ - the number of analysed samples; DON - deoxynivalenol; ZEN - zearalenone;

${ }^{a}$ Samples in which mycotoxin concentrations were higher than the limit of quantification (LOQ);

Results tagged with different letters $\left({ }^{\mathrm{a}, \mathrm{b}}\right)$ are statistically significantly different $(\mathrm{p}<0.05)$ 
The mean representation of ZEN positive samples obtained in this study was $94.3 \%$, the toxin concentrations thereby spanning from 0.3 to $88.6 \mu \mathrm{g} / \mathrm{L}$. The maximal mean value of $8.3 \pm 22.3 \mu \mathrm{g} / \mathrm{L}$ was determined in the central Croatia, while the lowest mean value of $2.0 \pm 2.5 \mu \mathrm{g} / \mathrm{L}$ was found in the samples coming from the Western region. Statistical analysis showed a statistically significant difference $(\mathrm{p}<0.05)$ in ZEN concentrations between the Croatian regions under study, the Northern region thereby being pinpointed as significantly different from the others. According to the 2004 EFSA opinion statement, ZEN has a limited tissue deposition and a low transmission rate into milk (EFSA, 2004). In accordance with the aforementioned, low ZEN levels in cattle and sheep liver, meat, milk and cheese have been reported. However, it was also observed that ZEN transfer into milk varies in its carry- over rates (Coffey et al., 2009). In the UK, ZEN was detected in $3 \%$ of milk samples at levels ranging from 1.2 to $5.5 \mu \mathrm{g} / \mathrm{L}$ (EC, 2003). The maximal obtained concentration was $12.5 \mu \mathrm{g} / \mathrm{L}$ (E1-Hoshy, 1999). Usleber et al. (1992) concluded that ZEN contamination is low even after high oral ZEN doses. But in contrast to these results, Mirocha et al (1981) found a high level of ZEN and its metabolites in concentration of $1,359 \mu \mathrm{g} / \mathrm{L}$ seven days after the administration of $200 \mathrm{mg}$ ZEN daily, given to dairy cattle.

Mirocha et al (1981) estimated the transfer rate of ZEN and its metabolites into milk to be $0.05 \%$. Yiannikouris and Jouany (2002) reported on ZEN transfer rates of $0.06 \%, 0.016 \%$ or $0.008 \%$, dependent on the toxin intake. Other studies have claimed these rates to be $0.00625 \%$ and $1.924 \%$ (Galtier, 1998). Winkler et al. (2015) estimated the rate of transfer of ZEN and its metabolites into milk to be $0.008 \%$. In view of the above, it can be concluded that human exposure to ZEN coming from milk is not to be considered a health risk, but studies have also pointed out that the toxicity of ZEN metabolites should be taken into consideration, for example that of $\alpha$-zearalenol, whose oestrogenic potential is three-fold higher than that of ZEN (Mirocha et al., 1981). Since in vitro studies have evidenced that the main representative of fumonisines, fumonisin Bl (FBl), was poorly metabolized in the rumen (Caloni et al., 2000), it was con- cluded that FBl could reach milk (Flores-Flores et al., 2015). In the study by Richard et al. (1996), after the implementation of dietary equivalent of FUM of approximately $75 \mathrm{mg} / \mathrm{kg}$ and the average of $3 \mathrm{mg} \mathrm{FBl} / \mathrm{kg}$ b.w./day, methods having a sensitivity of $5 \mu \mathrm{g} / \mathrm{L}$ failed to detect FUM in any of the milk samples. Also, a transmission study on four cows dosed with pure FB1 either orally or using an intravenous injection, showed no detectable residues of FUM in milk (Scott et al., 1994). Maragos and Richard (1994) reported FBl presence in only 1 out of 155 analyzed samples found in the concentration of $1.29 \mu \mathrm{g} / \mathrm{L}$, whereas in the study by Gazzotti et al. (2009) FBl was found in 8 out of 10 analysed milk samples in the maximal concentration of $0.43 \mu \mathrm{g} / \mathrm{L}$. Bottom-line, it has been concluded that in dairy cows the appearance of FUM in milk, or their carry-over from feed to milk, is not significant and does not represent a hazard or food safety concern when it comes to humans (Richard et al., 1996; EFSA, 2005).

However, in the recently published review, Flores-Flores et al. (2015) pointed out that, given that only a few studies investigated the possibility of carry-over of FUM from feed to milk and the obtained results were contradictory, more investigations of FUM contamination of milk on a large number of samples were needed. In the present study, FUM was not detected in any of the milk samples. Although a low FUM presence in milk samples analysed within this study cannot be dismissed, the LOQ of $25.3 \mu \mathrm{g} / \mathrm{L}$ established for the ELISA method employed within this study frame renders the detection of low FUM levels in milk impossible. Therefore, our further research shall seek for a more sensitive confirmatory technique capable of determining lower concentrations of this analyte in milk.

The mean and the maximum concentrations determined for DON and ZEA (no positives for FUM) were compared against the TDI values established for these mycotoxins, taking into account the available data on milk consumption across the Croatian population. The results descriptive of the estimated Fusarium mycotoxin intake through the milk consumption path are shown in Table 5 .

When it comes to the mean and the maximal concentration determined in milk, the calculations showed the DON intake (expressed as the percentage 
of the TDI) to be $9.7 \%$ and $31.0 \%$, respectively. The ZEN intake, expressed as the percentage of the TDI calculated based on the mean ZEN concentration determined within this frame was $12.9 \%$, but when the calculation used the maximal concentration determined in milk as the rationale, the obtained value was $203.6 \%$. Given that FUM were not detected in any of the milk samples, but taking also into account that FUM concentrations higher than $25.3 \mu \mathrm{g} / \mathrm{L}$ (i.e. the LOQ of the ELISA assay) were not possible to detect by the used method, we insofar presume that milk is not a significant source of these mycotoxins and, thus, does not pose a threat to human health.

Since milk represents only one component of human diet and in view of the fact that Fusarium mycotoxins can be present in a number of food groups, for instance cereals, their total intake (i.e. the percentage of the TDI actually entering the body) could be higher than estimated herein. Also, when it comes to specific population such as children, who consume higher amounts of milk a day, mycotoxin intakes could also be higher than here stated. In light of the foregoing, it is evident that the prevention of contamination of feedstuffs and foodstuffs with Fusarium mycotoxins is of a great importance for the protection of public health. To prevent their presence, the identification of key critical control points, which include production, processing and storage of food and feed, is essential. Measures taken to the above effect require the application of effective techniques capable of reducing the mycotoxin presence in food and feed or of decontaminating the latter. Systematic control over Fusarium mycotoxins using modern analytical methods should be implemented in order to prevent contamination of the entire food/feed chain from farm to table.

\section{Conclusions}

Levels of Fusarium mycotoxins in dairy cattle feedstuffs higher than recommended were evidenced for ZEN and DON and linked to extremely rainy conditions during the period of cereal growth and harvesting seasons. Given the TDIs defined for these mycotoxins, human health risks arising from the consumption of cow milk can be considered low, except for samples in which the maximal ZEN concentration was observed. Further studies are needed to determine a carry- over effect from commodities and dairy cattle feed products to cow milk, especially when it comes to DON and ZEA. Analytical method used for the determination of FUM should be of a higher sensitivity, so as to be able to detect lower concentrations of these contaminants in milk.

Table 5. Estimation of Fusarium mycotoxin intake through the milk consumption path, expressed as the percentage of the Tolerable Daily Intake (TDI)

\begin{tabular}{|c|c|c|c|c|c|c|}
\hline Mycotoxin & $\begin{array}{c}\text { TDI }^{\mathrm{a}} \\
(\mu \mathrm{g} / \mathrm{kg} \text { bw/day })\end{array}$ & Region & $\begin{array}{c}\text { Mean } \\
\text { concentration } \\
(\mu \mathrm{g} / \mathrm{L})\end{array}$ & $\%$ of TDI & $\begin{array}{c}\text { Maximal } \\
\text { concentration } \\
(\mu \mathrm{g} / \mathrm{L})\end{array}$ & $\%$ of TDI \\
\hline \multirow{5}{*}{$\mathrm{DON}$} & \multirow{5}{*}{1} & Central & 28.8 & 13.3 & 67.3 & 31.0 \\
\hline & & Eastern & 27.2 & 12.6 & 52.0 & 23.9 \\
\hline & & Western & 19.4 & 8.9 & 28.3 & 13.1 \\
\hline & & Northern & 9.1 & 4.1 & 16.4 & 7.6 \\
\hline & & In total & 21.1 & 9.7 & 67.3 & 31.0 \\
\hline \multirow{5}{*}{ ZEN } & \multirow{5}{*}{0.2} & Central & 8.3 & 19.3 & 88.6 & 203.6 \\
\hline & & Eastern & 3.8 & 8.6 & 60.3 & 138.6 \\
\hline & & Western & 2.0 & 4.6 & 14.0 & 32.1 \\
\hline & & Northern & 7.8 & 17.9 & 48.0 & 110.7 \\
\hline & & In total & 5.5 & 12.9 & 88.6 & 203.6 \\
\hline
\end{tabular}




\section{Prisutnost mikotoksina roda Fusarium u krmivima i kravljem mlijeku uzorkovanim sa hrvatskih farmi tijekom 2015. godine}

\section{Sažetak}

Mikotoksini mogu kontaminirati hranu životinjskog podrijetla putem carry-over efekta i predstavljaju potencijalni rizik za ljudsko zdravlje. Problem kontaminacije mikotoksinima iz roda Fusarium izražen je naročito tijekom kišovitih godina, koje ujedno karakteriziraju i značajne promjene temperature. Cilj ovog istraživanja bio je ispitati razinu fuzarijskih mikotoksina zearalenona (ZEN), deoksinivalenola (DON) i fumonizina (FUM) u kukuruznoj silaži $(n=21)$, koncentriranoj hrani za mliječne krave $(n=56)$ i uzorcima kravljeg mlijeka $(\mathrm{n}=105)$, uzorkovanih tijekom 2015. godine sa obiteljskih poljoprivrednih gospodarstava iz četiri hrvatske regije. Prisutnost mikotoksina određena je primjenom ELISA validiranih metoda. Utvrđena je visoka razina kontaminacije stočne hrane posebno za ZEN, s vrijednostima većim od preporučenih u 9,5\% uzoraka kukuruzne silaže. $\mathrm{Na}$ DON je bilo pozitivno 14,3 \% uzoraka mlijeka, s koncentracijom u rasponu od 5,4 do 67,3 $\mu \mathrm{g} / \mathrm{L}$. ZEN je određen u 94,3 \% uzoraka mlijeka, u rasponu od 0,3 do $88,6 \mu \mathrm{g} / \mathrm{L}$. FUM nije određen $u$ niti jednom od analiziranih uzoraka mlijeka. S obzirom na prihvatljiv dnevni unos (TDI) definiran za ove mikotoksine, zdravstveni rizik za ljude koji proizlazi iz konzumacije kravljeg mlijeka općenito se može smatrati niskim, čak i tijekom razdoblja koja karakteriziraju vremenski uvjeti pogodni za proizvodnju fuzarijskih mikotoksina u žitaricama, a koje se nadalje koriste kao hrana za muzne krave. Izuzetak predstavljaju pojedini uzorci mlijeka u kojima su određene visoke koncentracije ZEN.

Ključne riječi: mikotoksini roda Fusarium, kravlje mlijeko, mliječna goveda, krmiva, hrvatske farme

\section{References}

1. Caloni, F., Spotti, M., Auerbach, H. Op den Camp, H., Gremmels, J.F., Pompa, G. (2000): In vitro metabolism of fumonisin Bl by rumen microflora. Veterinary Research Communications 24 (6), 379-387. https://doi.org/10.1023/A:1006422200226

2. Cavret, S., Lecoeur, S. (2006): Fusariotoxin transfer in animal. Food and Chemical Toxicology 44, 444-453. https://doi.org/10.1016/j.fct.2005.08.021

3. Charmley, E., Trenholm, H.L., Thompson, B.K. (1993): Influence of level of deoxynivalenol in the diet of dairy cows on feed intake, milk production and its composition. Journal of Dairy Science 76, 3580-3587. https://doi.org/10.3168/jds.S0022-0302(93)77697-3

4. Coffey, R., Cummins, E., Ward, S. (2009): Exposure assessment of mycotoxins in dairy milk. Food Control 20, 239-249. https://doi.org/10.1016/j.foodcont.2008.05.011

5. Côté, L.M., Dahlem, A.M., Yoshizawa, T., Swanson, S.P., Buck, W.B. (1986): Excretion of deoxynivalenol and its metabolite in milk, urine, and feces of lactating dairy cows. Journal of Dairy Science 69, 2416-2423. https://doi.org/10.3168/jds.S0022-0302(86)80681-6

6. Dänicke, S., Winkler J. (2015): Invited review: Diagnosis of zearalenone (ZEN) exposure of farm animals and transfer of its residues into edible tissues (carry over). Food and Chemical Toxicology 84, 225-249. https://doi.org/10.1016/j.fct.2015.08.009

7. D'Mello, J.P.F., Placinta, C.M., Macdonald, A.M.C. (1999): Fusarium mycotoxins: a review of global implications for animal health, welfare and productivity. Animal Feed Science and Technology 80, 183-205. https://doi.org/10.1016/S0377-8401(99)00059-0

8. EC (2002): Commision Decision 2002/657/EC of 12 August 2002 implementing Council Directive 96/23/ EC concerning the performance of analytical methods and the interpretation of results. Official Journal of the European Union L 221, 8-36.

9. EC (2005): Commission Recommendation 2005/856/ EC of 6 June 2005 amending Regulation EC No 466/2001 as regards Fusarium toxins. Official Journal of the European Union L 143, 3-8.

10. EC (2006): Commission Recommendation 2006/576/ EC of 17 August 2006 on the presence of deoxynivalenon, zearalenone, ochratoxin A, T-2 and HT-2 and fumonisins in products intended for animal feeding. Official Journal of the European Union L 229, 7-9.

11. EFSA (2004): Opinion of the Scientific Panel on Contaminants in the Food Chain on a request from the Commission related to zearalenone as undesirable substance in animal feed. EFSA Journal 89, 1-35.

12. EFSA (2005): Opinion of the Scientific Panel on Contaminants in Food Chain on a request from the Commission related to fumonisins as undesirable substances in animal feed. EFSA Journal 235, 1-32.

13. EFSA (2012): Guidance of selected default values to be used by the EFSA Scientific Committe, Scientific Panels and Units in the absence of actual measured data. EFSA Journal 10 (3), 2579. https://doi.org/10.2903/j.efsa.2012.2579 
14. El-Hoshy, S.M. (1999): Occurrence of zearalenone in milk, meat and their products with emphasis on influence of heat treatments on its level. Archiv Für Lebensmittelhygiene 50, 140-143.

15. FAOSTAT (2014): http://faostat.fao.org/site/610/DesktopDefault.aspx?PageID=610\#ancor (10.07.2016).

16. Fink-Gremmels, J. (2008): Mycotoxins in cattle feeds and carry-over to dairy milk: a review. Food Additives and Contaminants. Part A 25 (2), 172-180. https://doi.org/10.1080/02652030701823142

17. Flores-Flores, M.E., Lizarraga, E., López de Cerain, A., González-Peñas, E. (2015): Presence of mycotoxins in animal milk: A review. Food Control 53, 163-176. https://doi.org/10.1016/j.foodcont.2015.01.020

18. Galtier, P. (1998): Biological fate of mycotoxins in animals. Revue De Medecine Veterinaire 149, 549-554.

19. Gazzotti, T., Lugoboni, B., Zironi, E., Barbarossa, A., Serraino, A., Pagliuca, G. (2009): Determination of fumonisin Bl in bovine milk by LC-MS/MS. Food Control 20 (12), 1171-1174. https://doi.org/10.1016/j.foodcont.2009.02.009

20. Glenn, A.E. (2007): Mycotoxigenic Fusarium species in animal feed. Animal Feed Science and Technology 137, 213-240. https://doi.org/10.1016/j.anifeedsci.2007.06.003

21. International Organization for Standardization. ISO 6497:2002. Animal feeding stuffs - Sampling.

22. International Organization for Standardization. ISO 6498:1998. Animal feeding stuffs - Preparation of test samples.

23. International Organization for Standardization. ISO 707:2008. Milk and milk products - Guidance on sampling.

24. Kalač, P. (2011): The effects of silage feeding on some sensory and health attributes of cow's milk: A review. Food Chemistry 125, 307-317. https://doi.org/10.1016/j.foodchem.2010.08.077

25. Keese, C., Meyer, U., Valenta, H., Schollenberger, M., Starke, A., Weber, I.A., Rehage, J., Braves, G., Danicke, S. (2008): No carry over of unmetabolised deoxynivalenol in milk of dairy cows fed high concentrate proportions. Molecular Nutrition \& Food Research 52 (12), 1514-1529. https://doi.org/10.1002/mnfr.200800077

26. Maragos, C.M., Richard, J.L. (1994): Quantitation and stability of fumonisins B1 and B2 in milk. Journal of AOAC International 77 (5), 1162-1167.

27. MHS (2014): Meteorological and Hydrological Service of the Republic of Croatia. http://klima.hr/ocjene_arhiva.php (10.07.2016).

28. Mirocha, C.J., Pathre, S.V., Robison, T.S. (1981): Comparative metabolism of zearalenone and transmission into bovine milk. Food and Cosmetics Toxicology 19, 25-30. https://doi.org/10.1016/0015-6264(81)90299-6

29. Placinta, C.M., D’Mello, J.P.F., Macdonald, A.M.C. (1999): A review of worldwide contamination of cereal grains and animal feed with Fusarium mycotoxins. Animal Feed Science and Technology 78, 21-37. https://doi.org/10.1016/S0377-8401(98)00278-8

30. Pleadin, J., Sokolović, M., Perši, N., Zadravec, M., Jaki, V., Vulić, A. (2012a): Contamination of maize with deoxynivalenol and zearalenone in Croatia. Food Control 28, 94-98. https://doi.org/10.1016/j.foodcont.2012.04.047
31. Pleadin, J., Perši, N., Vulić, A., Zadravec, M. (2012b): Survey of mycotoxin contamination in Croatia. Biotechnology in Animal Husbandry 28 (2), 167-177. https://doi.org/10.2298/BAH1202167P

32. Pleadin, J., Vahčić, N., Perši, N., Sevelj, D., Markov, K., Frece, J. (2013): Fusarium mycotoxins' occurrence in cereals harvested from Croatian fields. Food Control 32, 49-54. https://doi.org/10.1016/j.foodcont.2012.12.002

33. Pleadin, J., Frece, J., Vasilj, V., Markov, K. (2015): Fuzarijski mikotoksini u hrani i hrani za životinje. Croatian Journal of Food Technology, Biotechnology and Nutrition 10 (1-2), 6-13.

34. Prelusky, D.B., Veira, D.M., Trenholm, H.L., Foster, B.C. (1987): Metabolic fate and elimination in milk, urine and bile of deoxynivalenol following administration to lactating sheep. Journal of Environmental Science and Health. Part B 22 (2) 125-148. https://doi.org/10.1080/03601238709372550

35. Prelusky, D.B., Scott, P.M., Trenholm, H.L., Lawrence, G.A. (1990): Minimal transmission of zearalenone to milk of dairy cows. Journal of Environmental Science and Health. Part B 25 (1), 87-103. https://doi.org/10.1080/03601239009372678

36. Richard, J.L., Meerdink, G., Maragos, C.M., Tumbleson, M., Bordson, G., Rice, L.G., Ross, P.F. (1996): Absence of detectable fumonisins in the milk of cows fed Fusarium proliferatum (Matsushima) Nirenberg culture material. Mycopathologia 133 (2), 123-126. https://doi.org/10.1007/BF00439124

37. Scott, P.M., Delgado, T., Prelusky, D.B., Trenholm, H.L., Miller, J.D. (1994): Determination of fumonisins in milk. Journal of Environmental Science and Health. Part B 29 (5), 989-998. https://doi.org/10.1080/03601239409372913

38. Signorini, M.L., Gaggiotti, M., Molineri, A., Chiericatti, C.A., Zapata de Basílico, M.L., Basílico, J.C., Pisani, M. (2012): Exposure assessment of mycotoxins in cow's milk in Argentina. Food and Chemical Toxicology 50, 250-257. https://doi.org/10.1016/j.fct.2011.09.036

39. Usleber, E., Renz, V., Martlbauer, E., Terplan, G. (1992): Studies on the application of enzyme immunoassays for the Fusarium mycotoxins deoxynivalenol, 3-acetyldeoxynivalenol, and zearalenone. Zentralblatt Fur Veterinarmedizin. Reihe B 39 (8), 617-627. https://doi.org/10.1111/j.1439-0450.1992.tb01213.x

40. Warth, B., Sulyok, M., Berthiller, F., Schuhmacher, R., Krska, R. (2013): New insights into the human metabolism of the Fusarium mycotoxins deoxynivalenol and zearalenone. Toxicology Letters 220, 88-94. https://doi.org/10.1016/j.toxlet.2013.04.012

41. Winkler, J., Kersten, S., Valenta, H., Meyer, U., Engelhardt, G., Dänicke, S. (2015): Development of a multitoxin method for investigating the carry-over of zearalenone, deoxynivalenol and their metabolites into milk of dairy cows. Food Additives and Contaminants 32, 371380 .

42. Yiannikouris, A., Jouany, J.P. (2002): Mycotoxins in feeds and their fate in animals: A review. Animal Research 51, 81-89. https://doi.org/10.1051/animres:2002012 